\title{
Financing Government Through Monetary Expansion and Inflation
}

\author{
CHARLOTTE E. RUEBLING
}

O

VER THE last ten fiscal years Federal Government expenditures have exceeded Government receipts, primarily taxes, by more than $\$ 70$ billion. Over half of this cumulated deficit has been financed through monetary expansion. Faster growth of the money stock over this period, in turn, has led to an increased rate of inflation.

Monetary expansion and inflation engender some of the same effects as increases in taxes; they reduce the wealth of some members of the private sector and increase the Government's command over real resources. Unlike tax rates, however, rates of monetary expansion have not been legislated explicitly. Instead, they have resulted from the implementation of monetary policy in a framework where monetary policy actions are not independent of legislated budget decisions. This article discusses the mechanisms through which monetary expansion and inflation act similarly to taxes in that they finance Government and redistribute wealth.

The section entitled "Monetary Expansion" describes institutional arrangements which determine who, in the first instance, receives the spending power generated by monetary expansion. Banking laws, such as those pertaining to reserve requirements and interest payments, infuence the proportions of an increase in the money stock that accrue to the Government and to the stockholders, deposit holders, and loan cus. tomers of banks. Under the institutional arrangements prevailing in the United States and most other countries today, at least a portion of an increase in the money stock is a source of finance for the Government, which in turn benefits those who gain from Government spending and those who would otherwise be taxed as an alternative means of finance.

The section entitled "Inflation as a Tax" describes how unanticipated inflation transfers real wealth from net monetary creditors to net monetary debtors and how inflation, even though anticipated, is a tax on holding money. Because the Federal Government is a net monetary debtor and can create money, these transfers help to finance Government expenditures.

Rampant inflation can diminish the willingness of the private sector to accept money in exchange for goods and services. To the extent that anticipation of inflation has this effect, monetary expansion and inflation become less effective means for the Government to acquire and transfer resources. Limits to the effectiveness of inflationary finance are discussed in the last major section of the paper.

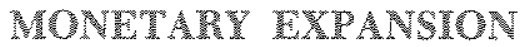

The gains which accrue to issuers of money are derived from the difference between the costs of issuing money and the initial purchasing power of new money in circulation. Such gains are called "seigniorage."1 If the goods and services for which the issuer exchanges money have a market value greater than that of resources used to produce the money, then the issuer receives a net gain. Banks, for example, gain if the stream of income purchased from a given amount of created deposit money exceeds the stream of costs of producing that money, including interest payments on deposits. In general, the costs of issuing money vary according to what serves as money and the conditions under which it is produced and supplied to the economy, while the initial purchasing power of new money depends on the demand for money in the economy and the quantity already in circulation.

1For a discussion of seigniorage, see Hubert C. Grubel, "The Distribution of Seigniorage from International Liquidity Creation," Monetary Problems of the International Economy, ed. Robert A. Mundell and Alexander K. Swoboda (Chicago: The University of Chicago Press, 1969), pp. 269-82; and Harry G. Johnson, "Appendix: A Note on Seigniorage and the Social Saving from Substituting Credit for Comnodity Mones," Monetary Problems, pp. 323-29.

Johnson shows two formulas for seigniorage.

$$
\underset{t=0}{\Sigma} \frac{v-c}{(1+i)^{t}}=(v-c) \frac{1+i}{i}
$$

where " $v$ " is circulating value, " $c$ " is the cost, and " $i$ " is the interest rate prevaling in the period between recoinages. He notes: "This expression differs from the usual formula for capitalized value of an income flow because the first yield accrues immediately." [Johnson, "Appendix," p. 323.]

$$
\begin{gathered}
{\left[(1-c)+\frac{(i-c)}{i} g\right] M=(i-c) \frac{(i+g)}{i} M=} \\
\frac{(i-c)}{i}(i+g) M
\end{gathered}
$$

where " $\mathrm{c}$ " is the real cost stream associated with a unit of the money stock, " $\mathrm{i}$ " is the interest rate on assets, " $\mathrm{g}$ " is the growth rate of demand for money at a stable price level, and " $\mathrm{M}$ " is the existing money supply. [Johnson, "Appendix," pp. 325-26.] 


\section{Costs of Issuimg Woney}

The costs of issuing money vary with the type of money. For commodity money, such as gold, the costs are reflected in the value of the commodity itself and in the expense of minting coins. The costs of issuing paper money are paper and engraving, and the costs of producing deposit money are bookkeeping and servicing the accounts.

The costs of producing a given amount and type of money also differ according to whether they are viewed as the outlays of the issuer or as the costs to society. From the point of view of society as a whole, the costs of producing money are the real resources absorbed and not available for use elsewhere. To society, then, interest payments on deposits are not a cost; they do not represent resources absorbed in the use of money, but rather a transfer of command over resources among members of the society. "The issuer of deposits, on the other hand, would view these interest payments as a cost.

The total real wealth of society is enhanced when fewer real resources are absorbed in the use of money, Under most circumstances the market value of resources required for a given amount of paper or deposit money is less than the market value of resources required for the same amount of commodity money. Hence, from the point of view of society, real costs are lower for paper and deposit money than for commodity money.

\section{The Demand for Monen}

Money is that asset which minimizes the costs of exchanging assets; in other words, it serves as a medituri of exchange. Money also serves as a relable form in which to hold purchasing power as long as the value of money in exchange is stable. Even if the general price level is not stable, money serves as a hedge against relative price shifts - for example, lange declines in the current price of common stocks relative to the prices of some other assets. Because of these services, people are willing to give up other

\footnotetext{
2 "ce in formula (2) in footnote 1 of this article would be a transfer of seigniorage from the issuers of money to the holders of money. See Johnson, "Appendix," p. 326.

3Karl Brumer and Allan H. Meltzer," The Uses of Money: Money in the Theory of an Exchange Economy," The American Economic Review (December 1971), pp. 801-2.

* Confidence in paper money is an important characteristic whose costs to sociefy may vary from time to time. See Benjamin Klein, "The Competitive Supply of Money" Journal of Money, Credit and Banking (November 1974), pp. 423-53.
}

goods and services in exchange for money. We would expect that the amount of money demanded at any given time depends on the importance of the services performed by money compared to other goods and services and on the reliability with which the particular form of money serves as a medium of exchange and a store of value. For example, as an economy increases in population, output, and complexity, the demand for the services of money would tend to rise. If, in addition, money holdings were expected to yield a return in terms of rising purchasing power over time, we would expect the amount of money demanded to rise further. On the other hand, an expected decline in the purchasing power of money would tend to depress the demand to hold wealth in the form of money.

\section{Who 1 sates Money and Who Gans from Rn whrsion of he Money Sock}

The assets which most consistently serve as money in our economy are currency, coin, and demand deposits. ${ }^{5}$ Currency and coin, which account for about one-fourth of these assets, are issued by the Treasury or Federal Reserve Banks. Demand deposits, which account for the remaining three-fourths of the money stock, are issued by commercial banks.

Even though private institutions issue the largest part of the money stock, the total amount of money in the economy is dominated by Federal Reserve and Treasury actions. Bank deposits are backed by reserves, and the Federal Reserve System and Treasury carry primary responsibility for the total amount of reserves and currency in our economy. In other words, the Federal Reserve and Treasury dominate the issue of "high-powered" money or "base" money, which consists of currency held by the public and bank reserves, as shown in Table I. ${ }^{6}$

The main sources of high-powered money are, of are closely related to, Treasury or Federal Reserve actions. A rise in the magnitude of the base restulting from a rise in the dollar value of the gold stock, for example, can occur through transactions involving the Treasury and Federal Reserve System following a

\footnotetext{
Demand deposits and currency in the hands of the public comprise the money stock as it is "narrowly defned" (MI). M2 is a broader meastre, adding time deposits other than large centificates of deposit at commercial banks to ML. M3 adds savings and loan and mutual savings bank deposits to M2.

oThere are several refinements of this magnitude - for example, source base and monetary base. See Leonall C. Andersen and Jerry L. Jordan, "The Monetary Base - Explanation and Aralytica Use," this Review (August 1968), pp. 7-11,
} 


\section{Sources of Base}

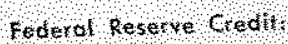
U.5 Government Securities?

loons

Flod Plus oller Federd Reserve Assols

Gold Stoek Plus Special Drowing Rights Certificate Aetount

Treasurh Currerey outstarding

Freosury bepoth al federol Restris Bonks

roreign oeposits with federd Reserte

treasury cash holdings, ofter liabilites ano Copital Acounts ond Other Federd Reperve Depotits

Source Base

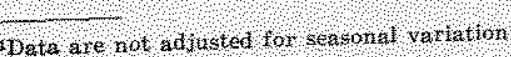

theluder Tederal atenes: issues:

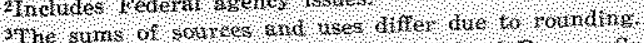

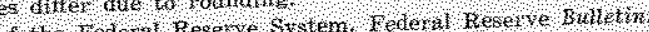

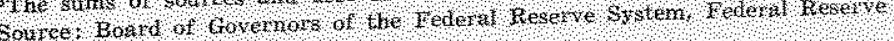

devaluation of the dollar. ${ }^{7}$ The largest source of the base and the one associated with most changes in the base is the expansion of Federal Reserve holdings of Government securities.

Money creation need not be a printing press operation in order for it to provide the Govemment with funds. Expansion of central bank holdings of Government debt provides the Treasury with funds just as certainly as increased output of its engraving and printing facilities. Over the last ten years Federal Reserve holdings of Government securities have risen by over $\$ 40$ billion. This increase, in turn, has served as a basis for growth of the money stock.

As mentioned above, commercial banks issue demand deposits, which comprise the major portion of our money stock. Demand deposits are issued on the basis of high-powered money that is not being used as currency in the hands of the public or as required reserves against deposits. When high-powered money enters the banking system, it becomes both a bank deposit and bank reserves. Since the proportion of deposits that banks are required to hold as reserves is less than 100 percent, high-powered money in the form of reserves enables the banking system to further expand the money stock by issuing additional deposits when they make loans. ${ }^{8}$

TSee Abert E. Burger. "The Monetary Economics of Gold," this Review (Jamuacy 194 (4), pp. 2-7,

speserve requirements on demand deposits at member banks currently range between 7.5 percent and 16.5 percent, depending on the dollar amount of weposits at the bank.
Commercial banks gain from issuing money if the stream of income from toans and investments, undertaken with reserves in excess of requirements, exceeds the costs of issung money. Banks make no explicit interest payments to holders of demand deposits, but do nevertheless incur costs in the servicing of accounts."

Commercial banks receive no interest paynents on the portion of their assets held as reserves either at Federal Reserve Banks or as vault cash. Hence, higher reserve requirements inhibit commercial banks' opportumities to gan from issuing deposits. If banks were required to hold reserves equal to 100 percent of deposits, the money stock would equal high-powered money and all proceeds from monetary expmsion would accrue to the Government alone.

A number of writers have noted that if there were competition in the issuance of money and no prohibition of interest payments on demand deposits, com peting banks would try to attract deposits by offering to pay interest on them. The outcome of the competition would be the transfer of gains from the issuers of money to the holders of money, that is, from bazk stockholders to bank deposit holders. Some have argned that such competition would lead to excessive

"Since 1933 commercial banks in the United States have been Trohibited by law from making explicit interest payments on grohibited by law rom jaking $\mathrm{N}$. O'Brien, "Interest Ban on demand deposits. See James M. O'Brien, Moterest Faderal Demand Deposits: Victim of the Proft Motive? (August

Reserve Bank of

1972), pp. 13-19. 
monetary growth. ${ }^{19}$ However, if competition in the payment of interest were accompanied by some minimum reserve requirements, then the Government would hold a constraint on monetary expansion.

In this case the public would no doubt be tempted to hold no currency at all, since it pays no interest, and to hold cash only in the form of bank deposits; ... The fact that banks may have legal or traditional reserve requirements, however, sets a lower limit on the ratio of currency (inchuding bank reserves) to deposits: the most extreme possibility is that all newly issued currency (along with all old currency) flows immediately into the reserves of the barking system, which then sssues new bank money in whatever ratio is permitted by its reserve ratio. ${ }^{11}$

Bank loan customers gain from monetary expansion when loans are made at interest rates below the market-clearing rate. Then part of the seigniorage that would otherwise accrue to a bank's stockholders goes to borrowers. This occurs to the extent that the yield on real resources acquired by the borrower is greater than the cost of acquiring them because the interest on the loan was below the appropriate market rate $^{12}$

\section{Who loses from the Frimacion of Seignionge by the Issucrs of Money?}

Those who experience lower wealth due to the ability of money issuers to obtain seigniorage essentially pay a tax to the issuer. The tax payment is the difference between actual wealth and what wealth would have been in the absence of seigniorage or if seigniorage were distributed as interest on holding money. Such losses may represent a social loss, that is, lower aggregate real wealth in the economy than under an alternative monetary arrangement.

... social welfare will be higher in a paper-money system with a fixed money supply than in one in which the money supply is expanded to keep the price level constant, because in the former system the falling trend of prices provides a yield to the holders of real balances and enconrages a greater use of money, which greater use increases welfare at no social cost. (This proposition is subject to the qualification that if prices fall at a percentage rate

19Tohnson, "Appendix" p. 32\%. For criticism and additional comment regarding this proposition, see Klein, "The Com petitive Supply of Money."

"Martin J, Bailey, "The Welfare Cost of Inflationary Fi. nance," The Joumal of Political Economiy (April 1956), p. 103.

i2lbid., p. 104. Phillip Cagan "The Monetary Dynamics of Hyperinflation," Studies in the Quantity Theory of Motey, ed. Milton Friedman (Chicago: The University of Chicago Press, 1956 ) , p. 79. greater than the rate of return on real assets, the public will want to hold money rather than real assets and the system is likely to break down.)

The issue of additional paper money at a rate sufficient to keep the price level constant yields seigniorage to the monetary anthority equal to the real value of the quantity of money multiplied by its rate of growth ... by comparison with a papermoney system in which the quantity of money is fixed (and subject to the qualification mentioned at the end of the previous paragraph), the levying of seigniorage by a monetary policy of maintaining stable prices involves a social loss, resilting from the restriction of the use of money as a consequence of its zero yield. In other words, the maintenance of a stable price level imposes an "inflation tax" on hold ers of money, by comparison with a policy of keeping the money supply constant and allowing prices to fall over time (subject again to the aformentioned qualification) ${ }^{13}$

\section{Srmmary}

Who gains and who loses from the expansion of paper and deposit money while the price level remains unchanged depends on institutional arrangements for the expansion of the money stock.

(1) If the Government were the sole issuer of money, all of the seigniorage would go to the Government. Members of the private sector who acquired additional money balances would give up real goods and services in exchange for the services of money. To them, the cost for the services of money would equal the value of the goods and services exchanged, while to the Government, the cost would be only the outlay for paper, printing and bookkeeping.

(2) In a system where the Government issued bank reserves and currency yielding no interest to holders, and banks issued demand deposits which required a 100 percent reserve backing, the result would be the same as for case (1) above.14

(3) If the conditions of (2) above held except that reserve requirements were less than 100 percent, commercial banks would have the opportunity to gain seigniorage on deposits issued in excess of the amount of required reserves. This opportunity would induce banks to offer interest on deposits; competition for deposit holders, in turn, would result in gains being distributed to deposit holders through interest pay-

\footnotetext{
33ohnson, "Appendix," p. 325.

14It makes little difference if reserves and curfency are issued primarily by the nation's central bank, as opposed to the Treasury, if net eamings of the central bank are re. turned to the Govermment Treasury, as is the practice in the United States.
} 
ments. There would still be a gain to the Government, but it would be less than in cases (1) and (2) because people would tend to hold money in the form which yielded interest - deposits rather than currency. Government seigniorage would be earned only on the proportion of deposits required as reserves.

(4) If the conditions of case (3) above held except that banks were prohibited from paying interest on deposits, seigniorage would be eamed by both the Govemment and banks. To the extent that banks charged an interest rate on loans less than an appropriate market rate, some of the banks' seigniorage would be distributed to loan customers.

\section{TNTITION AS A M H}

Some portion of monetary expansion which maintains a stable price level serves to finance Government spending, as discussed in the previous section. Rises in the price level, whether or not they are the result of monetary expansion, also serve to finance Government because of its status as a net monetary debtor and because of the progressive income tax. ${ }^{15}$ It will be shown that unanticipated inflation reduces the wealth of net monetary creditors to the benefit of net monetary debtors and that inflation, even if correctly anticipated, reduces the wealth of money holders in proportion to their hold. ings of money.

\section{Defintions}

Monetary assets are claims to a fixed amount of dollars. Money, bonds, and pensions without escalator clauses, and contracts to provide labor services for a fixed salary or wage are examples of monetary assets. ${ }^{16}$ Real assets, on the other hand, are claims to things whose dollar-value can vary. Houses, automobiles, and contracts to receive labor services are examples of real assets. Monetary habilities are obligations to deliver a fixed amount of dollars. Loans typically are obligations to pay a given amount of dollars - principal plus interest - and are therefore monetary liabilities to the borrower. Real habilities are

\footnotetext{
15With a progressive tax structure, as incomes and prices rise with inflation, income tax payments rise at a faster rate than prices have risen over the tax period. If income doubles, for example, as the result of inflation, with an uncharged progressive tax structure, income tax payments would mote than double for individuals in many tax brackets. The Govermment's income tax revenues would therefore also be more than double their preminflation level.

10 For a discussion of escalator clauses or "indexation", see lat-Hoon Yang, "The Case For and Against Indexation: An Atternpt at Perspective," this Review (October 1974), pp. 2-11.
}

obligations to deliver goods or services whose price may change between the time the obligation was negotiated and the time the goods and services are delivered. A contract to provide labor services is a real liability to the worker.

The net wealth of an economic unit is equal to the sum of its monetary assets and real assets less the sum of its monetary liabilities and real liabilities. On a balance sheet, net wealth and its components take the following positions:

$\begin{array}{ll}\frac{\text { Assets }}{\text { Monetary Assets }} & \frac{\text { Monetary Liabilities and Not Wealth }}{\text { Real Assets }} \\ & \text { Real Liabilities } \\ & \text { Net Wealth }\end{array}$

The sums of the two columns are equal. Net monetary creditors are those whose monetary assets exceed their monetary liabilities. Net monetary debtors are those whose monetary liabilities exced their monetary assets.

Inflation is a persistent decline in the purchasing power of money, or conversely, a persistent rise in the average price level of goods and services. Unanticipated inflation implies that market behavior is based on the expectation that the price level will rise at a slower rate than it actually does. ${ }^{17}$ Inflation may be partially unanticipated if market participants expect the price level to rise, but underestimate the extent of the rise. Anticipated inflation is where market participants correctly forese changes in the price level and make economic decisions accordingly.

\section{Unantipinated Intation and the Thanster from Net Monetary Creditors to Net Monetary Debions}

With inflation, the amount of dollars embodied in real assets and real liabilities tends to rise, while the amount of dollars claimed through monetary assets and committed through monetary liabilities remains fixed. Hence a change in the price level affects net wealth differently, according to the composition of net wealth. ${ }^{18}$

1.7Reubern A. Kessel and Amen A. Alchian, "Effects of Infation," The Jotmal of Political Econony (December 1962), p. 524 .

18For additional discussions of this topic, see Amen A. Alchian and Willam R. Allen, Untwersity Economics: Elements of Inquiry, 3rd ed. (Belmont, Californa: Wadsworth Publishing Comparty, Ince, 1972), pp. 674-81; $G$, L. Bach, The New Inflation: Causes, Effects, Cures (Providence: Brown Lniversity Press, 1972), p. 25; G. L. Bach and James B. Stephenson, "Inflation and the Redistribution of 


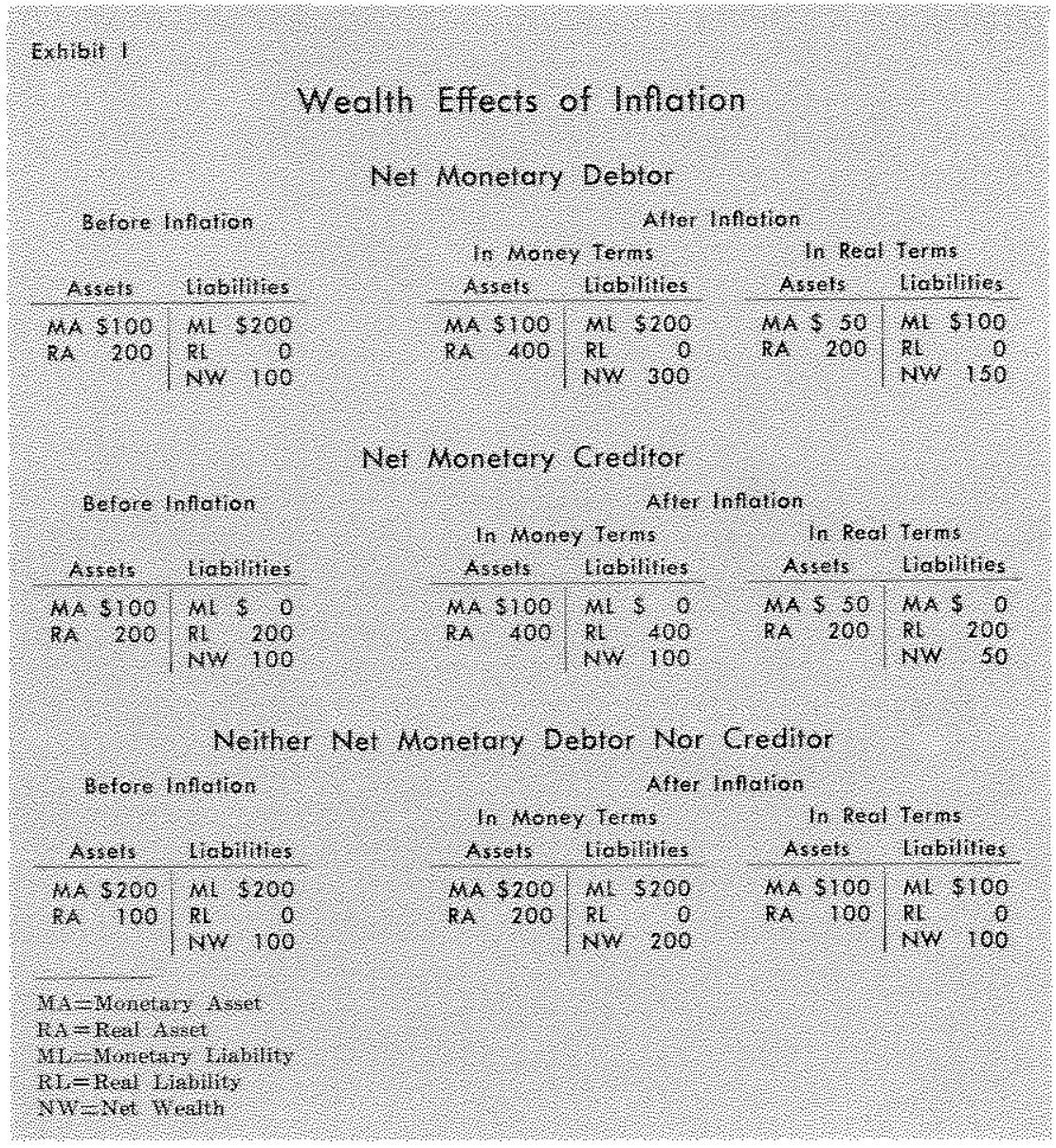

monetary assets and liabilities remain tnchanged. They are also shown in real terms, where monetary assets and liabilities have been deflated by the new price index $\left(P_{1}\right)$ while real assets and liabilities remain at their pre-inflation amounts.

The before- and after-inflation balance sheets show a decrease in real net wealth for the net monetary creditor, an increase for the net monetary debtor and no change for the one whose monetary assets equal monetary liabilities. ${ }^{19}$

It is important to regard the inflation in this illustration as unanticipated. A decline in the real net wealth of net monetary creditors means that the real yield on monetary assets after inflation turns out to be less than anticipated at the time of purchase. Expectations of prices rising at an accelerated rate in the future wonld motivate actions to offset the effect of inflation on net wealth. ${ }^{2}$ For example, such expectations would lead a lender to request a higher interest payment to compensate him for the reduced purchasing power of the dollar expected by the time of

Exhibit I shows the effect of inflation on three wealth holders. Before infation the net wealh of each is $\$ 100$, as shown in the balance sheets to the left. The composition of wealth, however, differs among them. The first is a net monetary debtor; monetary liabilities exceed monetary assets. The second is a net monetary creditor; monetary assets exceed monetary liabilities. The thind has equal amounts of monetary assets and monetary liabilities.

To the right of the exhibit are the after-inflation balance sheets of the three wealth holders. For purposes of illustration, inflation at a rate of 100 percent is viewed as a discrete event with the price level doubling in the period from $P_{0}$ to $P_{1}$ that is, $\left.P_{0}=1.00, P_{1}=2,00\right)$. The after-inflation balance sheets are shown first in money terms, where real assets and real liabilities double when prices double while

Wealth," The Review of Economics and Statistics (February 1974); Albert $\mathrm{E}$. Burger, "The Effects of Inflation (1960-68)" "his Review November 1969), pp. 25-36: W. Lee Hoskins, "Inflation Gamers and Losers," Federal Reserve Bank of Philadelphia Business Retiew (February 1970), pD. 23-30; Kessel and Alohian, "Effects of In tion," pp. $52 I-3 \%$. repayment. By the same token, expected increases in inflation would make a borrower more willing to pay a higher interest rate because the purchasing power of funds obtaned at the time the loan is made is expected to be greater than the purchasing power of funds at the time the loan is repaid. In a market where interest rates are free to vary, a lower interest rate than that which would compensate the leader for inflation results from underanticipation of inflation.

This reasoning suggests that expectations about changes in the price level will affect makket rates of

14t should be noted that in actuality not all real assets will rise in price at the same rate as the price level. Some real asset prices will rise faster, some slower. It also should be noted that tebt incurred to increase current consmmotion does not lead to a rise in real net wealth with inflation. In the case that debt is incurred for the purchase of nondumable goods, the rise in monetary liabilities is offset by a decline in net wealth on the same side of the balance sheet. Current consumption might be viewed as increasing real net wealth to the extent that it increases the value of the consmmer's human capital, but such an eflect would be diffeult to measure.

"Ceilings on interest payments by financial instifutions and other interest rate controls limit the range of inflationmoffsetting alternatives that monetary creditors can choose. 
interest. ${ }^{21}$ Expectations of a rise in the rate of inflation will lead to increased market interest rates. This is equivalent to a decline in the current exchange prices of outstanding monetary assets and liabilities."2 Hence, expectations of increased inflation, as well as the occurrence of inflation, cause reductions in the purchasing power of existing monetary assets.

\section{Whation and the U.S. Covernment Debt}

The ontstanding debt of the Federal Government is over $\$ 480$ billion. In addition, Federal agencies and trust funds, as of the third quarter of 1974, had an outstanding debt of $\$ 137$ billion. Most of the $\$ 480$ billion public debt has been incurred since 1941 . About $\$ 135$ billion of this is held by U.S. Goverument agencies and trust funds; about $\$ 80$ billion is held by the Federal Reserve System; and about $\$ 266$ billion is held by private investors.

Inflation, to the extent it is underanticipated at the time securities are issued, reduces the amount of purchasing power which the Government must repay to holders of maturing securities. For example, the repayment in 1972 of $\$ 1,000$ on a maturing five-year note issued in 1967 would buy roughly what only $\$ 805$ would have bought in 1967.23

The Government's debt consists of securities issued at various times, for various maturities, and at various interest rates. We cannot tell precisely the degree to which the inflation we have had has been anticipated or the degree to which interest payments have compensated purchasers for losses in the purchasing power of their monetary asset due to subsequent inflation. Probably, however, much of the inflation has been unanticipated. We can observe, for example, that if a $\$ 1,000$ five-year note was purchased at par in 1967 to yield 5 percent per yeart-t and held to maturity, interest receipts would have equalled $\$ 50$ per year or $\$ 250$ for the five years. Since, however, prices rose each year, each $\$ 50$ interest receipt would buy less than the previous one.

\footnotetext{
"A discession of the eflect of inllationary expectations on interest rates and mumerons reprences are contaned in Wiliam P. Yohe and Dens S. Karnosky. "Interest Rates and Price Level Changes, 1952-69," this "Review (Decenber 1069 ), pp $+8-38$.

227he exchange price of a monetary asset is the price which it can command in the market currenty. This can vary, whereas the dollar amotine to be obtaned at maturity remains fred

23) Defang by the GNP inplict price defator.

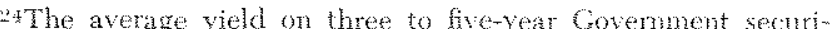
ties ranged between 4.5 and 5.5 parent during $196 \%$.
}

Table II shows the continual dechne in the purchasing power of the interest receipts compared to 1967.

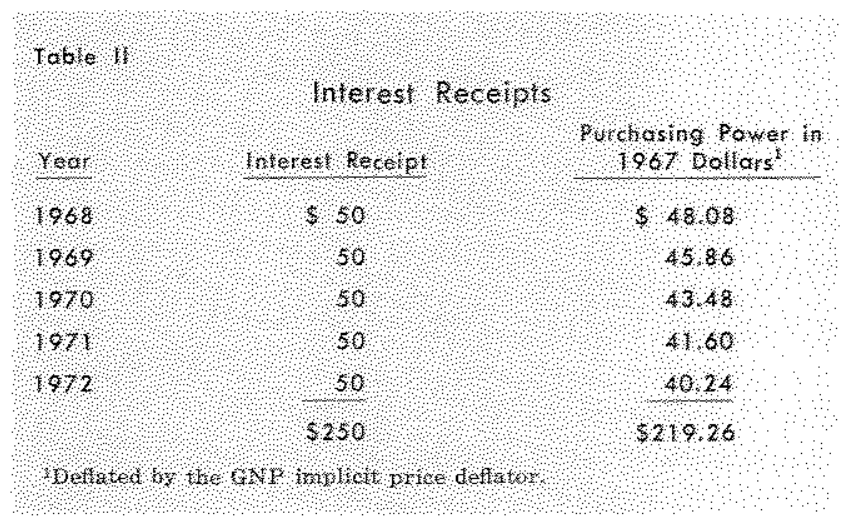

Ignoring possible remvestment of interest receipts, total interest payments in terms of 1967 purchasing power come to only $\$ 219$. With the $\$ 195$ loss in the purchasing power of the principal, offset by only a $\$ 219$ payment in real purchasing power for interest, the security holder received essentially nothing for allowing the Govermment to use his funds for five years.

The Govemment's commitment to redeem its secunities and pay interest on them is a commitment to pay a fixed number of dollars. Unanticipated inflation reduces the amount of real resources embodied in this commitment. Hence, inflation captares, from those who purchased bonds, resources which otherwise either would not be avalable for Governmental use or distribution or would have to be financed with other taxes. These resources, thus captured, constitute an arbitrary transfer from, or "tax" on, the wealth of the bondholders.

\section{The Inlation Tax on Money}

As mentioned earlier, inflation is the continuous erosion of the purchasing power of money. Those who continue to hold money as it decreases in purchasing power incur a loss. The loss is often described as a "tax" on money. The real value of money holdings is the tax base; the rate of infation is the rate of tax; the product of the base and rate is the negative impact of intation on the real wealth of the money holder. 25

\footnotetext{
"rBailey, "Weltare Cost," p. 93; Pinllp Cagan, The Chamels of Moneray Efferts on Interest Rates (New York: National Bureau of Econonic Research 1972), bp. 9-39, and "Nonetary Dylanuics" D. F8: Nitton Friedman "Govemment Reverne from indlation," The jound of Political Fonomy July Augue 1071 ) p 836
} 
Consider an example of someone holding $\$ 100$ in the form of money. Assume that at the end of a year the $\$ 100$ will purchase a market basket of goods equal to only $9 / 10$ of what it would have bought at the beginning of the year. This is the same as saying that the original basket costs $\$ 111.11$ at the end of the year, or that prices have risen by 11.1 percent, or that the original money holdings are worth only $\$ 90$ in purchasing power at the end of the year. The person holding the $\$ 100$ has paid a tax equal to 11.1 percent of that $\$ 90$. The rate of the tax is the rate of inflation (11.1 percent). The tax base is the real value of money balances ( $\$ 90)$. The tax payment, in real terms, is the product of the rate and base $(\$ 10)$.

A general formula describing the tax payment from an inflation tax is:

$$
\frac{M}{P_{1}} \times \frac{P_{1}-P_{B}}{P_{0}}
$$

where $M$ is the amount of money held, $P_{0}$ is the in itial price level, and $P_{1}$ is the price level after the inflation. In terms of the example in the previous paragraph where $P_{u}=1$ and $P_{1}=1.11$ :

$$
\frac{\$ 100}{1.11} \times \frac{1.11-1.00}{1.00}=\$ 90 \times .111=\$ 10
$$

The decrease in purchasing power incurred by holders of money due to inflation imparts gains to the issuers of money if the rises in the price level are due to increases in the quantity of money. The increases in the price level reveal to some extent the real resources acquired by the issuers of money through the expansion of money." In this case the inflation tax on money is an extension of the concept of seigniorage discussed earlier in the context of monetary expansion just sufficient to keep the price level stable.

Declines in the purchasing power of money due to declines in the real wealth of the community do not impart absolute gains to the issuers of money, ${ }^{27} \mathrm{Nev}-$ ertheless, to the extent that declines in real wealth are reflected in a rise in the price level, the declines are distributed in the community according to holdings of money.

\footnotetext{
26"Inflation can be deliberately utilized as a tax. A govern* ment can acquire resources by creating and spending new fiat money. This policy can cause prices to rise and it is this rise in prioes that reveals the transfer of wealth to the government from money holders and reduces the wealth position of all (including government) creditors," [Kessel and Alchian, "Effects of Intation," p. 525.]

27 Ibid., p. 527 .
}

\section{LIMTS TO TME ERECTUVENGSS OR MONETAPY EXPANSTON AND INFUATON AS SOURCES OF GOVERNMENT FUNDS}

\section{Anticipation of Inflation}

Once the public anticipates inflation, the gains in purchasing power the Government can derive from its ability to expand the money stock and issue debt become more limited. Anticipation of inflation leads to attempts by the public to economize on cash balances, and in the process they bid up prices of goods and services. The rise in prices reduces the real money stock which is the base of the inflation tax. ${ }^{28}$

A study of historical hyperinflations has shown that Government revenue from the inflationary finance was high at the beginning. However, as the experience of inflation was built into the expectations of the public and the public made adjustments on the basis of those expectations, real inflation tax revenues could

2s The effect of anticipated inflation on the inflation tax base and revenues is described more completely elsewhere. For example?

A higher rate of articipated inflation will produce larger tax proceeds per mnit of real value of money balances held by a community, but it also reduces stocks of money balances in real terms. [Ibid, p. 531.] and

The base of the tax is the level of real cash balances; the rate of the tax is the rate of depreciation in the real value of money, which is equal to the rate of rise in prices. Revenue (in real tems) from the tax is the product of the base and the rate,

$$
\frac{\mathrm{M}}{\mathrm{p}}\left(\frac{\mathrm{dP}}{\mathrm{dt}} \frac{\mathrm{l}}{\mathrm{P}}\right)
$$

The note-issuing anthorities 'collect' all the revenue; however, when prices rise in greater proportion than the quantity of money, that is, when real cash balances decline, part of the revente goes to reduce the real value of the outstanding money supply. Thus total reventue per period of time is the sum of two parts: farst, the real value of new money issued per period of time,

$$
\frac{\mathrm{dM}}{\mathrm{dt}} \frac{1}{\mathrm{P}}
$$

and, second, the reduction in outstanding monetary liabilities, equal to the dectine per period of time in the real value of cash balances,

$$
\frac{\mathrm{d}\left(\frac{\mathrm{M}}{\mathrm{P}}\right)}{\mathrm{dt}} \text {. }
$$

This is demonstrated by the following identity:

$$
\frac{\mathrm{d} M}{\mathrm{dt}} \frac{\mathrm{l}}{\mathrm{P}} \ldots \frac{\mathrm{d}\left(\frac{\mathrm{M}}{\mathrm{P}}\right)}{\mathrm{dt}}=\frac{\mathrm{M}}{\mathrm{P}}\left(\frac{\mathrm{dP}}{\mathrm{dt}} \frac{1}{\mathrm{p}}\right) \text {. }
$$

[Cagan, "Monetary Dynamics," p. 78.] 
be increased only by even more rapid rates of money growth.

Rates were quickly reached, however, that completely disrupted the economy, and they could not be long continued. The atternpt to enlarge the revenue in the closing months thus produced the characteristic pattern of the kyperinflations; price increases did not peter out; they exploded.2\%

Correct anticipation of inflation would also limit the opportunity of the Government to gair command over resources from inflationary policies through its status as a net monetary debtor. With anticipations of inflation, the pablic would buy securities only at a discount or at a yield which incorporated an inflation premium.

\section{Tax Structure}

As noted in footnote 15 of this article, our tax structure tends to yield increases in income tax revenues at a rate faster than inflation. Offsetting this influence, but only slightly, is the effect of capital losses due to inflation. Capital losses reduce taxable income and are realized when securities are sold at a discount, compared to the purchase price, due to an increase in the actual or anticipated rate of inflation.

\section{Competition in the Isste of Money}

Competition in the issue of money transfers gains from money creation to the holders of money, while issuers continue to earn a return sufficient to remain in business.

In the United States, institutional constraints limit the ability of private institutions to compete with the Government in the issue of money, but they do not eliminate it entirely. Commercial banks issue demand deposits on the basis of reserves which essentially are issued by the Govemment. Hence the gains to the

"Cagan, "Monetary Dynamics," p. 80. See also: Miltor Fredman, "Monetary Policy in Developing Countries," $\mathrm{Na}$ tions and Households in Economic Growth: Essays in Honor of Moses Abramovitz, ed. Panl A. David and Melvin W. Reder (New York: Academic Press, 1974), pp. 272-76; Friedman, "Government Revenue," and Bailey, "Weltare Cost," p. 101.
Government from the issue of money are in relation to the total of bank reserves ${ }^{3 *}$ and currency in the hands of the public, that is high-powered money, while the money stock consists of the larger total currency plus demand deposits in the hands of the public.

\section{SUMMARE}

Increases in the money stock, under institutional arrangements for monetary expansion in the United States and elsewhere, provide, in the first instance, purchasing power for the issuer of money - primarily the Government. Monetary expansion, whether accompanied by actual rises in the price level or not, taxes the wealth of money holders by making the purchasing power of their money holdings less than it would be in the absence of the expansion or under an arrangement where money holdess reaped all the gains from a larger stock of money services.

In addition, unanticipated price rises reduce the real value of monetary assets and liabilities and thus transfer wealth from net monetary creditors to net monetary debtors. The decrease in the real value of the Govermment debt due to inflation is a transfer of wealth from bondholders and money holders to taxpayers and to beneficiaries of Government spending programs. Correct anticipation of inflation would tend to reduce these transfers. In addition, changes in institutional arrangements, such as removal of the prohibition of interest payments on demand deposits, and indexation of income taxes and security prices would reduce the contributions of monetary expansion and inflation to Government finance.

Monetary expansion and inflation, like income and other taxes, redistribute purchasing power from the private sector to the public sector and among members of the private sector. Unlike other taxes, however, they are not legislated specifically, but come about primarily as the result of actions of the monetary authorities.

39 Reserves of commercial banks that are nembers of the Federal Reserve.

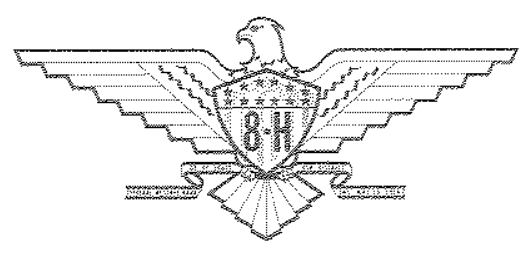

